\title{
10-13 Yaş Grubu Çocuklarda Oyunsal Etkinliklerin Dikkat
}

\section{Gelişimine Etkisi}

Mesut RENK ${ }^{1}$ (D)

Serkan İBiş ${ }^{2}$
Zait Burak AKTUĞ ${ }^{2 *}$ (D)

\footnotetext{
${ }^{1}$ Niğde Ömer Halisdemir Üniversitesi, Sosyal Bilimler Enstitüsü, Beden Eğitimi ve Spor, NİĞDE

${ }^{2}$ Niğde Ömer Halisdemir Üniversitesi, Spor Bilimleri Fakültesi, $N \dot{I} \breve{G} D E$
}

DOI: 10.31680/gaunjss.675451

Orijinal Makale / Original Article

Geliş Tarihi / Received: 15.01 .2020
Kabul Tarihi / Accepted: 26.05.2020

\section{Öz}

$\mathrm{Bu}$ çalışmanın amacı, oyunsal etkinliklerin ve fiziksel aktivite düzeyinin dikkat gelişimi üzerine etkisinin incelenmesidir. Çalışmaya 10-13 yaş arasında 209 kız ve 230 erkek olmak üzere toplam 439 çocuk katılmıştır. Çocuklar kontrol grubu ve 14 hafta boyunca dikkati geliştirmeye yönelik eğitsel oyun oynayan deney grubu olmak üzere iki gruba ayrımıştır. Çocukların dikkat düzeyi D2 dikkat testi ile, fiziksel aktivite düzeyi ise ilköğretim öğrencileri için fiziksel aktivite anketi ile belirlenmiştir. Grupların ön testleri ile son testleri arasındaki farkı belirlemede Paired t testi kullanılmıştır. Çalışma sonucunda hem deney grubunun hem de kontrol grubunun dikkat düzeylerinin son testte arttığı belirlenirken, deney grubundaki artışın kontrol grubuna göre daha yüksek olduğu bulunmuştur. Ayrıca fiziksel aktivite düzeyi yüksek olan çocukların dikkat düzeylerinin de yüksek olduğu belirlenmiştir. Günümüzde çocukların en büyük sorunu olan dikkat eksikliğini engellemek için fiziksel aktivite seviyesinin ve oyunsal etkinliklerle geçirilecek zamanın artırıması gerektiği söylenebilir. Bu bağlamda ebeveyn ve öğretmenlerin, çocukların dikkat gelişimini artırmak için ders programının içeriklerine, içerisinde fiziksel hareketleri de barındıran eğitsel oyunları ilave etmesi önerilebilir.

Anahtar Kelimeler: Çocuk, Oyun, Dikkat Düzeyi, Fiziksel Aktivite Seviyesi

\section{The Effect of Game Activities on the Attention Development for Children in 10-13 Age Group}

\begin{abstract}
The purpose of the present study is to examine the effect of game based activities on the attention development. The participants are 439 children, 209 of whom are female and 230 are male. The participants have been divided into two as control group and experimental groups, which were given educational games for attention development for 14 weeks. We have used D2 attention test for the determination of participants' levels of attention and physical activity survey for their levels of physical activeness. We have used paired t test for determining the difference between the pre-test and post-test. As a result of the study, it was found that both the experimental group and the control group increased their attention levels in the post test, while the increase in the experimental group was higher than the control group. In addition, children who high level of physical activity have high levels of attention. It can be said that the level of physical activity and the time spent with play activities should be increased in order to prevent attention deficit which is the biggest problem of children. In this context, it may be suggested that parents and teachers should add educational games including physical movements to the content of the curriculum to increase children's attention development.

Keywords:Child, Game, Attention Level, Physical Activity Level
\end{abstract}

\footnotetext{
* Sorumlu Yazar: Zait Burak AKTUĞ

E-mail: zaitburak@gmail.com *Bu çalışma Niğde Ömer Halisdemir Üniversitesi, Sosyal Bilimler Enstitüsü’nde Yüksek Lisans tezi olarak sunulmuştur.
} 


\section{Giriş}

Çocuklar özellikle hareket edebilme ve oyun oynama isteğine bağlı olarak öğrenirler. Hareketlerine ne kadar çok duyu yolunu katarlarsa ilişkilendirme düzeyleri o kadar artar ve dolayısıyla öğrenme düzeyi de bu duruma bağlı olarak gelişim gösterir. Hareket programları ve oyunlar yoluyla çocuğun, alan, yön, dokunsal beden farkındalığı gelişir ve akademik yetilerin gelişmesinin zemini oluşturulmuş olur (Gallahue, 1976; Garn ve Byra, 2002). Giderek artan nüfus, teknolojik alandaki gelişmelere bağlı olarak çeşitlenen bilgisayar oyunları ve çarpıklaşan kentleşme sonucu daralan oyun alanları gibi nedenlerden dolayı çocuklar aktif oyun ve spor etkinliklerini terk etmekte ve bu olumsuzluklar çocuklarda birçok sağlık sorunlarını beraberinde getirmektedir (Ayan ve Memiş, 2012). Bu büyük bir problem durumudur, çünkü çocukluk yaşamının her döneminde oyun çocuk için en önemli uğraşlardan biridir (Gelen ve Özer, 2010). Zira çocuk öğrenme, karar verme, işbirliği, sıralama, düzenleme, paylaşma, başkalarının hakkına saygı gösterme, yardımlaşma gibi davranışları oyun sırasında öğrenir. Oyun sayesinde çocuk yetişkinliğinde gerekli olacak becerileri pratik yapar, değerlendirir ve mükemmelleştirir (Ayan ve Memiş, 2012).

Kirriemur ve McFarlane (2004) göre ise oyunlar öğretici ve yol gösterici olmaları bakımından eğitimde kullanılmaya uygundur. Bunun nedenleri arasında, oyunda kişinin yaparak-yaşayarak öğrenmesi, oyunların öğrenci merkezli olması, problemin çözüm aşamasında öğrencilerin aktif olarak rol alabilmeleri, etkileşimli uygulama imkanı sunabilmesi ve öğrenme için motivasyon sağlaması yer alır. Bu sebeple beden eğitimi derslerinde dikkat ve hafıza gelişimine yol açabilecek, temel hareket ve hareket örüntülerine dayanan planlanmış oyun ve benzeri etkinlikler oldukça yararlı olabilmektedir. Bu sayede çocukların algılama, hafıza ve dikkat yetileri artmaktadır (Yurdakul ve ark., 2012).

Dikkat, duyusal mekanizmalarla alınan uyaranlardan herhangi birinin, diğer durumlardan belli amaçlara göre seçilip ayıklanması işlemidir. Her durumun özgün koşullarına göre, diğerlerinden seçilerek ayıklanan ve üzerinde yoğunlaşılan uyaran grubu farklılaşabilir. Bu durum, dikkatin organizmanın duyduğu gereksinimler açısından yönlendirilen ve yapılandırılan bir süreç olması ile ilişkilidir (Aydın, 2000; Öztürk ve Kısaç, 2010). Dikkat eksikliği genellikle okul çağı çocuklarında sıkça görülen bir problem olmakla beraber (Küçük ve ark., 2009) fiziksel aktivite (Yurdakul ve ark., 2012; Pişkin ve Alpay, 2019; Kartal ve ark., 2016) ve oyunsal etkinliklerin 
çocuklarda dikkati olumlu yönde etkilediği yapılan çalışmalarda belirtilmiştir (Akandere ve ark., 2010; Gözalan, 2013; Dağdelen ve Kösterelioğlu, 2015).

Bu bilgiler doğrultusunda çalışmamızda 10-13 yaş grubu çocuklarda oyunsal etkinliklerin ve fiziksel aktivite düzeyinin dikkat gelişimi üzerine etkisinin incelenmesi amaçlanmıştır.

\section{Yöntem}

\section{Araştırma Grubu}

Araştırmanın çalışma evreni Osmaniye il merkezinde yaşayan, 10-13 yaş grubu çocuklardan oluşmuştur. Örneklem grubunu ise bu evren içerisinden ulaşılabilir örneklem yoluyla rastgele yöntem ile seçilen 209 kız ve 230 erkek olmak üzere toplam 439 çocuk (deney grubu= 220; kontrol grubu= 219) oluşturmaktadır. Çocukların fiziksel aktivite düzeyleri fiziksel aktivite anketi ile Dikkat düzeyleri ise D2 dikkat testi ile belirlenmiştir. Çalışmanın amacı ve içeriği çocuklara anlatılarak gönüllü olur formu alınmıştır. Çocukların dikkat düzeyleri çalışma başlamadan önce ve 14 hafta boyunca haftada 3 kez 45 dakikalık çeşitli dikkat ve koordinasyon içerikli oyunlar oynatıldıktan sonra olmak üzere iki kez ölçülmüştür. Deney grubundaki çocuklara oynatılan oyunlar seçilirken, oyun içeriklerinde fiziksel aktivitenin olmasına ve dikkat gerektirmesine özen gösterilmiştir. 14 hafta boyunca oynatılan oyunların adları "mevsimler oyunu, on pas oyunu ve kör bekçi" oyunudur.

\section{Verilerin Toplanması}

\section{İlköğretim Öğrencileri İçin Fiziksel Aktivite Anketi}

Çocukların fiziksel aktivite düzeyinin belirlenmesinde kullanılan ilköğretim öğrencileri için fiziksel aktivite anketi Crocker ve ark (1997) tarafından geliştirilmiş olup, Sert ve Temel (2014) tarafından Türkçe'ye uyarlanmıştır. Fiziksel aktivite ölçeği çocukların yalnız başına doldurabileceği bir ölçektir. Ölçek 8-14 yaş aralığındaki çocukların 7 gün boyunca yapılan genel fiziksel aktivite seviyelerini değerlendirir. Çocukların son bir hafta içerisinde yapılan aktiviteleri hatırlamaya yöneliktir. Bu ölçek sınıf ortamında uygulanabilir. Yine ölçek katılımcıların genel fiziksel aktivite alışkanlıkları konusunda bilgilendirir. Bu ölçekten alınan 5 puan en iyi fiziksel aktivite seviyesini belirtirken 1 puan ise en kötü veya düşük fiziksel aktivite düzeyini ifade eder. Fiziksel aktivite puanlarının değerlendirilmesinde tüm soruların toplam ortalaması dikkate alınır. Çalışmaya katılan çocuklar, bu ölçekten elde edilen 
değerlere göre aktif olmayan, orta düzeyde aktif ve aktif olmak üzere kategorilendirilir.

\section{D2 Dikkat Testi}

Brickenkamp (1962) tarafından geliştirilen D2 dikkat testi'nin 11-14 yaş grubu için Türkiye'ye uyarlama çalışması Toker (Toker, 1988; Toker, 1990) tarafından yapılmıştır. D2 dikkat testi seçici dikkat ve zihinsel konsantrasyonun bir ölçümüdür. D2 dikkat testinin ön sayfasında deneğin kişisel bilgileri ve performans sonuçlarının kaydedileceği bölüm ve bir deneme satırı yer almaktadır. Arka sayfada ise standart test formu bulunmaktadır. Test sayfası, her birinde 47 işaretli harf bulunan 14 satırdan oluşmaktadır. Her satırda bir, iki, üç ve dört küçük işareti olan "p" ve "d" harflerinden oluşan 16 farklı harf bulunmaktadır. Test sırasında denek, ilgili olmayan diğer harfleri görmezden gelerek iki işareti olan "d" harflerini bulmak ve üzerini çizmek için satırları taramak zorundadır. Her satır için deneğe 20 saniye süre verilir. D2 Testi'nden elde edilen puanlar ve anlamları aşağıda verilmiştir. İşlenen Toplam Madde Sayısı (TN): Hem ilgili hem de ilgili olmayan, işlenen tüm maddelere ilişkin performansın niceliksel ölçümüdür. Toplam Hata $(E)$ : İşaretlenmemiş (E1) ve yanlış işaretlenmiş harfleri (E2) kapsar. Hata Yüzdesi (\%E): Performansın niteliksel yönünü ölçen bir değişkendir. İşlem gören tüm maddeler içinde yapılan hata oranını temsil eder. Hata oranı azaldıkça, deneğin doğruluğu, işin niteliği ve dikkatlilik derecesi artar. Konsantrasyon Performansı (CP): Doğru olarak işaretlenen ilgili madde sayısından, E2'nin çıkarılması ile elde edilir. Dalgalanma Oranı (FR): İşlem gören maksimum madde sayısının bulunduğu sıra ile minimum madde sayısının bulunduğu sıra arasındaki farktır. Toplam Madde-Hata (TN-E): Taranan toplam madde sayısı eksi hata puanlarıdır. TN-E, bir toplam performans puanıdır, yüksek düzeyde güvenilirdir ve performansın doğruluğu ve hızı arasındaki ilişkinin ölçümünü verir. Elde edilen TN-E puanın yüzdelik dilimlerine göre \% 50-60 kötü, \% 60-70 vasat, \% 70-85 normal, \% 85 üzeri ise iyi olarak tanımlanır (Çağlar ve Koruç, 2006).

\section{Verilerin analizi}

Veriler SPSS 24.00 paket programında analiz edilmiştir. Verilerin normallik dağılımı Kolmogorow Smirnov ile belirlenmiş, veriler normal dağılım gösterdiğinden dolayı ön test ve son test arasındaki farkı belirlemede Paired $t$ testi kullanmıştır. 
Dikkat ve fiziksel aktivite düzeylerinin kategorilendirilmesi yüzde frekans analizi ile belirlenmiştir. Çalışmada anlamlılık düzeyi $p<0,05$ olarak kabul edilmiştir.

\section{Bulgular}

Tablo 1. Cinsiyetlere Göre TNE Düzeylerinin Kategorilendirilmesi Yüzdelik Dağılımları

\begin{tabular}{|c|c|c|c|c|c|c|c|c|c|}
\hline & & \multicolumn{4}{|c|}{ Deney Grubu } & \multicolumn{4}{|c|}{ Kontrol Grubu } \\
\hline & & \multicolumn{2}{|c|}{$\bar{K} \mathbf{\prime z}$} & \multicolumn{2}{|c|}{ Erkek } & \multicolumn{2}{|c|}{$\mathrm{K} \mathbf{\prime z}$} & \multicolumn{2}{|c|}{ Erkek } \\
\hline & & $\mathbf{N}$ & $\%$ & $\bar{N}$ & $\%$ & $\mathbf{N}$ & $\%$ & $\mathbf{N}$ & $\%$ \\
\hline \multirow{4}{*}{$\begin{array}{c}\text { Ön } \\
\text { Test }\end{array}$} & Kötü (\%50-60) & 29 & 26,13 & 26 & 23,85 & 31 & 31,63 & 43 & 35,54 \\
\hline & Vasat (\%61-70) & 11 & 9,91 & 22 & 20,18 & 12 & 12,24 & 21 & 17,36 \\
\hline & Normal (\%71-85) & 24 & 21,62 & 13 & 11,93 & 10 & 10,20 & 16 & 13,22 \\
\hline & İyi (\%86 ve Üzeri) & 47 & 42,34 & 48 & 44,04 & 45 & 45,92 & 41 & 33,88 \\
\hline \multirow{4}{*}{$\begin{array}{l}\text { Son } \\
\text { Test }\end{array}$} & Kötü (\%50-60) & 19 & 17,12 & 16 & 14,68 & 27 & 27,55 & 40 & 33,06 \\
\hline & Vasat (\%61-70) & 4 & 3,60 & 3 & 2,75 & 7 & 7,14 & 8 & 6,61 \\
\hline & Normal (\%71-85) & 22 & 19,82 & 31 & 28,44 & 19 & 19,39 & 28 & 23,14 \\
\hline & İyi (\%86 ve Üzeri) & 66 & 59,46 & 59 & 54,13 & 45 & 45,92 & 45 & 37,19 \\
\hline
\end{tabular}

Tablo 1 incelendiğinde deney grubunda iyi kategorisinde olanlar ön testte kızlarda \% 42,34 iken, son testte \%59,46’ya çıkmıştır. Erkeklerde ise ön testte $\% 44,04$ iken, son testte bu oran \%54,13'e çıkmıştır. Kontrol grubunda ise iyi kategorisinde olanlar kızlarda ön testte $\% 45,92$ son testte $\% 45,92$ iken, erkeklerde ön testte $\% 33,88$ son testte $\% 37,19$ 'dur. 
Tablo 2. Cinsiyetlere Göre Deney ve Kontrol Grubunun Fiziksel Aktivite Düzeyleri ile TNE Düzeylerinin Yüzdelik Dağılımları

\begin{tabular}{|c|c|c|c|c|c|c|c|c|c|}
\hline & & & \multirow{2}{*}{$\begin{array}{l}\text { TNE Düzey } \\
\text { Kötü (\%50-60) }\end{array}$} & \multicolumn{2}{|c|}{ Düşük FAD } & \multicolumn{2}{|c|}{ Orta FAD } & \multicolumn{2}{|c|}{ Yüksek FAD } \\
\hline \multirow{16}{*}{ Kız } & \multirow{8}{*}{ Deney Grubu } & & & 1 & 3,40 & 27 & 93,10 & 1 & 3,40 \\
\hline & & \multirow{3}{*}{ Ön Test } & Vasat (\%61-70) & 0 & 0,00 & 9 & 81,80 & 2 & 18,20 \\
\hline & & & Normal (\%71-85) & 4 & 16,70 & 18 & 75,00 & 2 & 8,30 \\
\hline & & & İyi (\%86 ve Üzeri) & 3 & 6,40 & 39 & 83,00 & 5 & 10,60 \\
\hline & & \multirow{4}{*}{ Son Test } & Kötü (\%50-60) & 1 & 5,30 & 17 & 89,50 & 1 & 5,30 \\
\hline & & & Vasat (\%61-70) & 0 & 0,00 & 4 & 100,00 & 0 & 0,00 \\
\hline & & & Normal (\%71-85) & 1 & 4,50 & 20 & 90,90 & 1 & 4,50 \\
\hline & & & İyi (\%86 ve Üzeri) & 6 & 9,10 & 52 & 78,80 & 8 & 12,10 \\
\hline & \multirow{8}{*}{ Kontrol Grubu } & \multirow{4}{*}{ Ön Test } & Kötü (\%50-60) & 6 & 19,40 & 23 & 74,20 & 2 & 6,50 \\
\hline & & & Vasat (\%61-70) & 1 & 8,30 & 9 & 75,00 & 2 & 16,70 \\
\hline & & & Normal (\%71-85) & 2 & 20,00 & 8 & 80,00 & 0 & 0,00 \\
\hline & & & İyi (\%86 ve Üzeri) & 4 & 8,90 & 39 & 86,70 & 2 & 4,40 \\
\hline & & \multirow{4}{*}{ Son Test } & Kötü (\%50-60) & 4 & 14,80 & 22 & 81,50 & 1 & 3,70 \\
\hline & & & Vasat (\%61-70) & 2 & 28,60 & 4 & 57,10 & 1 & 14,30 \\
\hline & & & Normal (\%71-85) & 3 & 15,80 & 13 & 68,40 & 3 & 15,80 \\
\hline & & & İyi (\%86 ve Üzeri) & 4 & 8,90 & 40 & 88,90 & 1 & 2,20 \\
\hline \multirow{16}{*}{ Erkek } & \multirow{8}{*}{ Deney Grubu } & \multirow{4}{*}{ Ön Test } & Kötü (\%50-60) & 0 & 0,00 & 24 & 92,30 & 2 & 7,70 \\
\hline & & & Vasat (\%61-70) & 0 & 0,00 & 16 & 72,70 & 6 & 27,30 \\
\hline & & & Normal (\%71-85) & 1 & 7,70 & 11 & 84,60 & 1 & 7,70 \\
\hline & & & İyi (\%86 ve Üzeri) & 1 & 2,10 & 37 & 77,10 & 10 & 20,80 \\
\hline & & \multirow{4}{*}{ Son Test } & Kötü (\%50-60) & 0 & 0,00 & 15 & 93,80 & 1 & 6,30 \\
\hline & & & Vasat (\%61-70) & 0 & 0,00 & 3 & 100,00 & 0 & 0,00 \\
\hline & & & Normal (\%71-85) & 0 & 0,00 & 24 & 77,40 & 7 & 22,60 \\
\hline & & & İyi (\%86 ve Üzeri) & 2 & 3,40 & 46 & 78,00 & 11 & 18,60 \\
\hline & \multirow{8}{*}{ Kontrol Grubu } & \multirow{4}{*}{ Ön Test } & Kötü (\%50-60) & 2 & 4,70 & 41 & 95,30 & 0 & 0,00 \\
\hline & & & Vasat (\%61-70) & 3 & 14,30 & 13 & 61,90 & 5 & 23,80 \\
\hline & & & Normal (\%71-85) & 1 & 6,30 & 14 & 87,50 & 1 & 6,30 \\
\hline & & & İyi (\%86 ve Üzeri) & 2 & 4,90 & 35 & 85,40 & 4 & 9,80 \\
\hline & & \multirow{4}{*}{ Son Test } & Kötü (\%50-60) & 3 & 7,50 & 37 & 92,50 & 0 & 0,00 \\
\hline & & & Vasat (\%61-70) & 1 & 12,50 & 7 & 87,50 & 0 & 0,00 \\
\hline & & & Normal (\%71-85) & 2 & 7,10 & 19 & 67,90 & 7 & 25,00 \\
\hline & & & İyi (\%86 ve Üzeri) & 2 & 4,40 & 40 & 88,90 & 3 & 6,70 \\
\hline
\end{tabular}

Tablo 2'de fiziksel aktivite düzeyine göre deney grubunda son testte bu dağııım performans puanı iyi olanlar lehine artmıştır. 
Tablo 3. Deney Grubunun Cinsiyete göre D2 Dikkat Testi Puanlarının Ön ve Son Test Sonuçları Karşılaştıııması

\begin{tabular}{|c|c|c|c|c|c|c|c|c|}
\hline & & & & & & & & \\
\hline & & Test aşama & $\bar{N}$ & Ortalama & SS & Sd & $\bar{T}$ & $\bar{p}$ \\
\hline & \multirow{2}{*}{ TN } & Ön Test & 111 & 428,29 & 94,95 & \multirow{2}{*}{110,00} & \multirow{2}{*}{0,61} & \multirow{2}{*}{0,54} \\
\hline & & Son Test & 111 & 426,16 & 81,00 & & & \\
\hline & \multirow{2}{*}{ E1 } & Ön Test & 111 & 56,86 & 50,13 & \multirow{2}{*}{110,00} & \multirow{2}{*}{11,13} & \multirow{2}{*}{0,00} \\
\hline & & Son Test & 111 & 32,82 & 29,87 & & & \\
\hline \multirow{6}{*}{ Kız } & \multirow{2}{*}{ E2 } & Ön Test & 111 & 23,29 & 31,62 & \multirow{2}{*}{110,00} & \multirow{2}{*}{4,26} & \multirow{2}{*}{0,00} \\
\hline & & Son Test & 111 & 16,08 & 15,50 & & & \\
\hline & \multirow{2}{*}{$\mathrm{CP}$} & Ön Test & 111 & 97,52 & 46,58 & \multirow{2}{*}{110,00} & \multirow{2}{*}{$-12,98$} & \multirow{2}{*}{0,00} \\
\hline & & Son Test & 111 & 126,79 & 32,80 & & & \\
\hline & \multirow{2}{*}{$\begin{array}{c}\text { TNE } \\
\text { YÜZDELIK }\end{array}$} & Ön Test & 111 & 72,70 & 26,39 & \multirow{2}{*}{110,00} & \multirow{2}{*}{$-5,00$} & \multirow{2}{*}{0,00} \\
\hline & & Son Test & 111 & 80,81 & 23,55 & & & \\
\hline & \multirow{2}{*}{ TN } & Ön Test & 109 & 417,75 & 96,92 & \multirow{2}{*}{108,00} & \multirow{2}{*}{0,16} & \multirow{2}{*}{0,87} \\
\hline & & Son Test & 109 & 417,18 & 84,90 & & & \\
\hline & \multirow{2}{*}{ E1 } & Ön Test & 109 & 48,64 & 47,74 & \multirow{2}{*}{108,00} & \multirow{2}{*}{9,58} & \multirow{2}{*}{0,00} \\
\hline & & Son Test & 109 & 29,93 & 29,24 & & & \\
\hline \multirow{6}{*}{ Erkek } & \multirow{2}{*}{ E2 } & Ön Test & 109 & 29,45 & 34,98 & 10000 & $5 G 0$ & קח \\
\hline & & Son Test & 109 & 20,99 & 20,82 & 100,00 & 3,00 & 0,0 \\
\hline & ת & Ön Test & 109 & 95,98 & 48,83 & & & \\
\hline & $\mathrm{CP}$ & Son Test & 109 & 122,29 & 36,46 & 108,00 & $-12,94$ & 0,00 \\
\hline & TNE & Ön Test & 109 & 71,44 & 28,87 & 0 & 57 & Pח \\
\hline & YÜZDELİK & Son Test & 109 & 79,88 & 23,85 & 100,00 & $-5,12$ & 0,00 \\
\hline
\end{tabular}

$\overline{p<0,05}$

Deney grubunda hem kızlarda hem de erkeklerde dikkat testi ön ve son testinde psikomotor hızda istatistiksel olarak anlamlı bir farklılık bulunmazken $(p>0,05)$, seçici dikkat veya işaretlenmemiş olma (E1), öğrenme güçlüğü ve yanlış işaretleme (E2), konsantrasyon performansı (CP) ve TNE Yüzdelik puanları arasında istatistiksel olarak anlamlı bir farklılık bulunmuştur $(p<0,05)$. 
Tablo 4. Kontrol Grubunun Cinsiyete göre D2 Dikkat Testi Puanlarının Ön Test ve Son Test t-Testi Sonuçları karşılaştırıması

\begin{tabular}{|c|c|c|c|c|c|c|c|c|}
\hline & & Test aşama & $\mathbf{N}$ & Ortalama & SS & Sd & $\bar{T}$ & $\mathbf{p}$ \\
\hline \multirow{10}{*}{$\mathrm{K} \mathbf{} \mathbf{z}$} & \multirow{2}{*}{ TN } & Ön Test & 98 & 434,55 & 103,42 & 97,00 & 0,15 & 0,88 \\
\hline & & Son Test & 98 & 434,12 & 94,03 & & & \\
\hline & \multirow{2}{*}{ E1 } & Ön Test & 98 & 63,51 & 52,77 & 97,00 & 8,10 & 0,00 \\
\hline & & Son Test & 98 & 55,72 & 46,51 & & & \\
\hline & \multirow{2}{*}{ E2 } & Ön Test & 98 & 22,26 & 21,09 & 97,00 & 3,09 & 0,00 \\
\hline & & Son Test & 98 & 20,52 & 17,10 & & & \\
\hline & \multirow{2}{*}{$\mathrm{CP}$} & Ön Test & 98 & 98,19 & 47,84 & 97,00 & $-5,46$ & 0,00 \\
\hline & & Son Test & 98 & 104,92 & 45,53 & & & \\
\hline & \multirow{2}{*}{$\begin{array}{c}\text { TNE } \\
\text { YÜZDELIK }\end{array}$} & Ön Test & 98 & 69,73 & 29,43 & 97,00 & $-3,43$ & 0,00 \\
\hline & & Son Test & 98 & 73,18 & 27,31 & & & \\
\hline \multirow{10}{*}{ Erkek } & \multirow{2}{*}{$\mathrm{TN}$} & Ön Test & 121 & 395,51 & 105,14 & 120,00 & 0,60 & 0,55 \\
\hline & & Son Test & 121 & 393,93 & 99,23 & & & \\
\hline & \multirow{2}{*}{ E1 } & Ön Test & 121 & 46,12 & 45,37 & 120,00 & 8,76 & 0,00 \\
\hline & & Son Test & 121 & 39,27 & 40,01 & & & \\
\hline & \multirow{2}{*}{ E2 } & Ön Test & 121 & 29,86 & 28,29 & 120,00 & 6,53 & 0,00 \\
\hline & & Son Test & 121 & 25,44 & 22,35 & & & \\
\hline & \multirow{2}{*}{$\mathrm{CP}$} & Ön Test & 121 & 90,13 & 50,78 & 120,00 & $-10,30$ & 0,00 \\
\hline & & Son Test & 121 & 99,41 & 47,95 & & & \\
\hline & \multirow{2}{*}{$\begin{array}{c}\text { TNE } \\
\text { YÜZDELIK }\end{array}$} & Ön Test & 121 & 64,75 & 30,66 & 120,00 & $-3,24$ & 0,00 \\
\hline & & Son Test & 121 & 68,51 & 29,56 & & & \\
\hline
\end{tabular}

Kontrol grubunda hem kızlarda hem de erkeklerde dikkat testi ön ve son testinde toplam maddede istatistiksel olarak anlamlı bir farklılık bulunmazken $(p>0,05)$, seçici dikkat veya işaretlenmemiş $(E 1)$, öğrenme güçlüğü veya yanlış işaretlenmiş (E2), konsantrasyon performansı (CP) ve TNE Yüzdelik puanları arasında istatistiksel olarak anlamlı bir farklıık bulunmuştur $(p<0,05)$. 
Tablo 5. Deney ve Kontrol grubunda ön teste göre son testte artma ve azalma yüzdeleri dağılımı

\begin{tabular}{cccc}
\hline \multirow{4}{*}{ Kılar } & D2 test & Deney grubunda artma ve düşme \% & Kontrol grubunda artma ve düşme \% \\
\cline { 2 - 4 } & TN & $-0,5$ & $-0,5$ \\
\cline { 2 - 4 } & E1 & $-42,48$ & $-12,27$ \\
\cline { 2 - 4 } & CP & $-30,96$ & $-7,82$ \\
\cline { 2 - 4 } & TNE \% & $+30,01$ & $+6,85$ \\
\hline \multirow{3}{*}{ Erkekler } & TN & $+11,16$ & $+4,95$ \\
\cline { 2 - 4 } & E1 & $-0,14$ & $-0,4$ \\
\cline { 2 - 4 } & E2 & $-38,47$ & $-14,86$ \\
\cline { 2 - 4 } & CP & $-28,73$ & $+15,47$ \\
\cline { 2 - 4 } & TNE $\%$ & $+27,41$ & $+10,26$ \\
\hline
\end{tabular}

Tablo 5'de görüldüğü üzere her iki cinsiyette de hem deney hem de kontrol gruplarında ön teste göre son testte TN, E1 ve E2 parametrelerinde yüzdesel olarak azalma, buna karşılık CP ve TNE\% değerlerinde yüzdesel olarak artma belirlenmiştir.

\section{Tartışma ve Sonuç}

Oyunsal etkinliklerin 10-13 yaş grubu çocuklarda dikkat gelişimine etkisinin incelendiği çalışmamızda son testte hem kontrol grubunda hem de deney grubunda D2 dikkat testi parametrelerinden E1, E2, CP ve TNE yüzdeliklerinde gelişim sağlandığı belirlenmesine karşın, deney grubundaki gelişimin kontrol grubuna göre daha yüksek düzeyde olduğu görülmüştür. Diğer bir deyişle uygulanan eğitsel oyunların çocukların dikkat gelişimini arttırdığı söylenebilir (Tablo 3,4,5). Ayrıca çocukların dikkat düzeyinin sınıflandırılmasında (TNE düzey) son teste deney grubunda iyi kategorisindeki artışın yüksek olduğu belirlenmiştir (Tablo 1).

Benzer bir çalışmada Akandere ve ark (2010) 9-13 yaşları arasındaki öğrencilere 8 hafta süre ile eğitsel oyun uygulamışlar ve deney grubunun dikkat değerlerinin kontrol grubunun dikkat değerlerine göre daha iyi olduğunu belirtmişlerdir. Başka bir çalışmada Gözalan (2013) oyunsal içeriği fazla olan dikkat eğitim programının çocuklarda dikkat ve dil becerilerini geliştirdiğini belirlemiştir. Dağdelen ve Kösterelioğlu (2015) çalışmalarında ilkokullardaki oyun ve fiziki etkinlikler dersinin öğretmenlerin görüşlerine göre birçok açıdan öğrenciyi geliştirdiğini belirtmişlerdir. Bir diğer çalışmada dikkat eksikliği bulunan çocuklarda 
oyun teknikleriyle çocuklarda olumlu yönde değişiklikler meydana geldiği tespit edilmiştir (Uskan, 2011).

Literatürde belirtilen bu çalışmalar çalışmamızın sonucunu destekler nitelikte olup, oyunsal etkinliklerin 10-13 yaş grubu çocuklarda dikkat düzeyini geliştirdiğini göstermektedir. Bu durum, çocukların oyun içerisindeki karmaşık olayları ve soyut kavramları anlamaları esnasında düşünme ve duyusal alan becerilerini geliştirmeleri (Varışoğlu ve ark., 2013) yolu ile dikkat düzeylerinin artmasından kaynaklı olabilir.

Çalışmamızda fiziksel aktivite düzeyleri incelendiğinde öğrencilerin fiziksel aktivite düzeyleri hem deney hem de kontrol grubunda kızlarda ve erkeklerde birbirine benzerdir. Ön test son test bulgularımıza göre fiziksel aktivite düzeyi arttıkça çocukların dikkat dağınıklığı probleminin azaldığı söylenebilir.

İbiş ve Aktuğ (2018) 10-14 yaşları arasındaki çocuklarda dikkat eksikliği kategorilendirilmesinde (TN-E düzeyi) spor yapan çocukların spor yapmayan çocuklara göre iyi sınıfında fazla, kötü sınıfında ise daha düşük sayıda olduğunu belirtmişlerdir. İbiş ve Aktuğ (2018) çalışma sonucunda sporun dikkat eksikliği bulunan çocuklarda olumlu bir etki yarattığını söylemiştir. Adsız (2010) çalışmasında, spor yapan ilköğretim öğrencilerinin spor yapmayanlara göre dikkat düzeylerinin \%83 daha iyi olduğunu belirtmiştir. Bu durum bize fiziksel aktivite düzeyinin önemini göstermektedir. Literatürde bu durumu destekleyen birçok çalışma mevcuttur. Bunlardan birisi de Göktepe ve ark (2016) tarafından kayak sporu yapan çocuklar ile spor yapmayan çocukların dikkat seviyelerinin incelendiği çalışmadır. Bulgulara göre kayak sporu yapan çocukların dikkat seviyelerinin spor yapmayan çocuklara göre daha iyi olduğu belirlenmiştir. Golf branşı yapan çocukların incelendiği başka bir çalışmada 8 hafta boyunca golf sporu yapan çocukların dikkat düzeylerinin artı̆̆ı görülmüştür (Tunç ve ark., 2014). Kartal ve ark (2016) tarafından yapılan bir çalışmada eskrim sporu yapan 10-12 yaş grubu çocukların, yapmayanlara göre dikkat düzeylerinin daha iyi olduğu tespit edilmiştir.

Yukarıda belirtilen çalışmalar bulgularımızı destekler nitelikte olup, fiziksel aktivite düzeyinin artmasının 10-13 yaş grubu çocuklarda dikkat düzeyini geliştirebileceğini göstermektedir.

Yapılan çalışmada dikkat düzeyinin ön test ve son test yüzdesel değişiklikleri incelenmiş, sonuç olarak deney grubundaki olumlu değişiklerin daha yüksek olduğu belirlenmiş̧ir. Örneğin işaretlenmeden atlanılan figür sayısı deney grubunda kızlarda ön teste göre son testte $\% 42,48$, kontrol grubunda $\% 12,27$ düşmüştür. Yine 
erkeklerde E1 değeri ön teste göre son testte deney grubunda \%28,73, kontrol grubunda $\% 15,47$ düşmüştür. Konsantrasyon performansı ise deney grubunda kızlarda \%30, kontrol grubunda \%6,85 artmıştır. Yine erkeklerde konsantrasyon performansı deney grubunda $\% 27,41$, kontrol grubunda $\% 10,26$ artmıştır.

Bu durumu destekleyen bir çalışmada Pişkin ve Alpay (2019) kort tenisinde 8 haftalık hedef çalışmalarının dikkat düzeyi üzerine etkilerini incelemiştir. Çalışmaya 10-12 yaş arası toplam 60 çocuk katılmıştır. Çocuklar kontrol grubu $(n=30)$ ve deney grubu $(n=30)$ olarak ikiye ayrılmıştır. Çalışma sonucunda hem deney hem de kontrol grubunda dikkat düzeylerinde artış meydana gelmiş, fakat bu artış deney grubunda yüzdesel olarak daha yüksek bulunmuştur. Küçük ve ark (2009) çalışmalarında ilerleyen yaşla birlikte dikkat düzeylerinin arttığını tespit etmişlerdir. Çünkü dikkat normal gelişimsel süreç ile doğru orantılıdır (Taş ve ark., 2009). Bu sebeple kontrol grubundaki artışın sebebi, zamanla büyümeye bağlı gelişimden kaynaklanabilir. Deney grubunda bu etkenlere ilaveten oynanan oyunların etkisi olduğu düşünülmektedir.

Oyunsal etkinliklerin 10-13 yaş grubu çocuklarda konsantrasyon performansı ve dikkat dağınıkığı problemi yüzdelik puanları arasında anlamlı bir farklılık meydana getirdiği görülmüştür. Eğitilebilir dikkat dağınıklığı problemi deney grubunda hem kızlarda hem de erkeklerde azalmıştır. Sonuç olarak günümüzde çocukların en büyük sorunu olan dikkat eksikliğini engellemek için fiziksel aktivite seviyesinin artırıması ve çocukların hayatında oyunsal etkinlere daha fazla yer verilmesi gerektiği düşünülmektedir. Ebeveyn ve öğretmenlerin ise çocukların dikkat gelişimini arttırmak için ders programının içeriklerine eğitsel oyunları ilave edilmesi önerilebilir.

\section{Kaynaklar}

Adsız E. (2010). İlköğretim çağındaki öğrencilerde düzenli yapılan sporun dikkat üzerine etkisinin araştırılması. Yüksek Lisans Tezi. Ege Üniversitesi Sağlık Bilimleri Enstitüsü. İzmir.

Akandere M., Baştuğ G., Asan R., Baştuğ K. (2010). Çocuklarda eğitsel oyunun dikkat üzerine etkisi. International scientific conference "Perspectives in Physical Education and Sport", 21-23 May. Constanta, Romania.

Ayan S., Memiş UA. (2012). Erken çocukluk döneminde oyun. Selçuk Üniversitesi Beden Eğitimi ve Spor Bilim Dergisi, 14(2), 143-149.

Aydın A. (2000). Gelişim ve öğrenme psikolojisi, Alfa Yayınları, İkinci baskı, İstanbul. 
Brickenkamp R. (1962). Aufmerksamkeits-Belastungs-Test (Test d2). 1st ed. Göttingen: Hogrefe.

Crocker PRE., Bailey DA., Faulkner RA., Kowalski KC., McGrath R. (1997). Measuring general levels of physical activity: preliminary evidence for the physical activity questionnaire for older children. Medicine and Science in Sports and Exercise, 29(10), 1344-1349.

Çağlar E., Koruç Z. (2006). D2 dikkat testinin sporcularda güvenirliği ve geçerliği. Spor Bilimleri Dergisi, 17(2), 58-80.

Dağdelen O., Kösterelioğlu İ. (2015). İlkokullardaki oyun ve fiziki etkinlikler dersinin öğretmen görüşlerine göre değerlendirilmesi. Adıyaman Üniversitesi Sosyal Bilimler Enstitüsü Dergisi, 8(19), 97-128.

Gallahue LD. (1976). Motor development and movement experiences for young children. Newyork. John Wiley and Sons.

Garn A., Byra M. (2002). Psychomotor, cognitive, and social development spectrum style. Teaching Elementary Physical Education, 13(2), 8-13.

Gelen İ., B Özer. (2010). Oyunlaştırmanın 5. sınıf matematik dersinde problem çözme becerisi ve derse karşı tutum üzerindeki etkisi. E-journal of New World Sciences Academy, 5(1), 71-88.

Göktepe M., Akalın TC., Göktepe MM. (2016). Kayak sporu yapan çocukların dikkat düzeylerinin incelenmesi. International Journal of Science Culture and Sport, 4(3), 722-731.

Gözalan E. (2013). Oyun temelli dikkat eğitim programının 5-6 yaş çocuklarıın dikkat ve dil becerilerine etkisinin incelenmesi. Yayınlanmamış Yüksek Lisans Tezi, Selçuk Üniversitesi, Sosyal Bilimler Enstitüsü, Konya.

İbiş S., Aktuğ ZB. (2018). Effects of sports on the attention level and academic success in children. Educational Research and Reviews,13(3), 106-110.

Kara M. (2010). Oyunlarla yabancılara Türkçe öğretimi. Türklük Bilimi Araştırmaları Dergisi, 27, 407-421.

Kartal R., Dereceli Ç., Kartal A. (2016). Eskrim sporu yapan ve yapmayan 10-12 yaş arası çocukların dikkat düzeylerinin incelenmesi. Sportif Bakış: Spor ve Eğitim Bilimleri Dergisi, 3(2), 82-88.

Kirriemuir J., McFarlane A. (2004). Literature review in games and learning (Futurelab Series, Report 8). Bristol, UK: Futurelab. 
Küçük A., Dolu N., Erdoğan H. (2009). İlköğretim öğrencilerinde yaş, cinsiyet ve sosyo-ekonomik seviye farklılılarının dikkat düzeyine etkileri. Sağlık Bilimleri Dergisi, 18(1), 18-24.

Öztürk B., Kısaç İ. (2010). Bilgiyi işleme modeli, eğitim psikolojisi gelişim öğrenmeöğretim. 6. Baskı (Edt. Yeşilyaprak, B.). Pegem Akademi, Ankara.

Pişkin NE., Alpay CB. (2019). Çocuklarda 8 haftalık kort tenis antrenmanının dikkat düzeyi üzerine etkisinin incelenmesi. Beden Eğitimi ve Spor Bilimleri Dergisi, 13(1), 11-17.

Sert Z., Temel A. (2014). Illköğretim öğrencileri için fiziksel aktivite soru formunun Türk toplumuna uyarlanması: geçerlik ve güvenirlik çalışması. Dokuz Eylül Üniversitesi Hemşirelik Fakültesi Elektronik Dergisi, 7(2), 109-114.

Taş FV., Emiroğlu N., Akay A. (2009). Çocuk psikiyatrisi polikliniğinde dikkat eksikliği ve aşırı hareketlilik yakınması ile değerlendirilen hastaların psikososyal gelişim özellikleri. Yeni Sempozyum Dergisi, 47(1), 3-8.

Toker MZ. (1988). Standardization of the visual attention test D2 on a Turkish sample. Yayımlanmamış yüksek lisans tezi. İstanbul: Boğaziçi Üniversitesi.

Toker MZ. (1990). D2 dikkat testinin uyarlama çalışması. Psikoloji- Seminer Dergisi, 8, 627-635.

Tunç A., Akandere M., Baştuğ G. (2014). The analysis of the attention levels of individuals playing golf. Turkish Journal of Sport and Exercise, 16(1), 104-115.

Uskan C. (2011). Dikkat eksikliği bozukluğu olan 8-10 yaşındaki çocukların dikkat becerilerini geliştirmeye dayalı bir programın etkililiğinin sınanması. Yüksek Lisans Tezi, Maltepe Üniversitesi Sosyal Bilimler Enstitüsü, İstanbul.

Varışoğlu B., Şeref I., Gedik M., Yılmaz İ. (2013). Türkçe dersinde uygulanan eğitsel oyunlara yönelik tutum ölçeği: geçerlilik ve güvenilirlik çalışması. Adıyaman Üniversitesi Sosyal Bilimler Enstitüsü Dergisi, 6(11), 1060-1081.

Yurdakul NA., Çamlıyer H., Karabulut N., Soytürk M. (2012). Sekiz yaş grubu çocuklarda hareket eğitiminin dikkat ve hafıza gelişimine etkileri. Selçuk Üniversitesi Beden Eğitimi ve Spor Bilimleri Dergisi, 14(1), 103-108. 